Digital Hardware Design 


\section{Digital Hardware Design}

\section{Ivor Catt}

David Walton

Malcolm Davidson

M 
(C) Ivor Catt, David Walton and Malcolm Davidson 1979

All rigints reserved. No part of this publication may be reproduced or transmitted, in any form or by any means, without permission.

First published 1979 by

THE MACMILLAN PRESS LTD

London and Basingstoke

Associated companies in Delhi Dublin

Hong Kong Johannesburg Lagos Melbourne

New York Singapore and Tokyo

Typeset in 10/12 Times by

Reproduction Drawings Ltd Sutton, Surrey

\section{British Library Cataloguing in Publication Data}

Catt, Ivor

Digital hardware design.

1. Digital electronics

I. Title II. Walton, David, b.1947

III. Davidson, Malcolm

621.3815 TK7868.D5

ISBN 978-0-333-25981-8

DOI 10.1007/978-1-349-04481-8

This book is sold subject to the standard conditions of the Net Book Agreement.

The paperback edition of this book is sold subject to the condition that it shall not, by way of trade or otherwise, be lent, resold, hired out, or otherwise circulated without the publisher's prior consent in any form of binding or cover other than that in which it is published and without a similar condition including this condition being imposed on the subsequent purchaser. 


\section{Contents}

$\begin{array}{ll}\text { Preface } & \text { vii }\end{array}$

1 Introduction 1

2 The Interconnection of Logic 4

3 The Analogy between $L, C$ and $R \quad 7$

4 Transmission Line Theory Applied to Logic Interconnection 15

5 Component Pulse Response 27

6 Distribution of D.C. Power to Logic 36

7 Local Decoupling of Voltage Supplies by Printed Circuit Voltage Planes 39

8 Printed Circuit Board Layout for High Speed Schottky TTL 43

9 Crosstalk 55

10 Energy Current 65

11 Grounding in a Digital System 69

12 Grounding in a System Comprising More Than One Module 73 
13 Interference from the $50 / 60 \mathrm{~Hz}$ Line

14 Filtering the Line

15 Oscilloscopes for Digital Measurements 


\section{Preface}

The authors, who have long experience of research and development in digital electronics, became concerned at the lack of attention paid to the design of digital hardware by educational establishments. This book is based on material developed for a series of seminars which are now attended by engineers drawn from the design laboratories of many large electronics companies in the United Kingdom.

If and when colleges and faculties of electronics and physics realise that digital hardware design is a major discipline, this and subsequent volumes planned by the authors will be invaluable for the design of relevant and up-to-date courses.

I. CATT

D. S. WALTON

M. DAVIDSON 